\title{
Verification of the reaction to fire of water-based and oil-based enamel paints used as finish of walls in residential buildings
}

\author{
Guilherme Hennemann ${ }^{1}$, Henrique Eugênio ${ }^{1}$, \\ Fabrício Bolina ${ }^{1}$, Eduardo Rodrigues ${ }^{1}$, \\ Bernardo Tutikian $^{1}$
}

\footnotetext{
${ }^{1}$ Faculty of Engineering - Universidade do Vale do Rio dos Sinos, CEP: 93022-750, São Leopoldo, RS, Brasil. e-mail: guilhermeghennemann@gmail.com, henrique@opusalis.com.br, fabriciolb@unisinos.br, estevam.ecr@gmail.com, bftutikian@unisinos.br
}

\begin{abstract}
Among that materials whose behavior facing fire has not yet been understood thoroughly lie paints used as finish of interior and exterior walls of buildings. This study aimed to analyses the reaction to fire of enamel paints exposed to elevated temperatures, so two paints were tested: one water-based and one oil-based, both applied over a white undercoat designed specifically for this purpose, simulating the real conditions of application. The paints were evaluated regarding their ignitability per ISO 11925-2:2010 and isolated combustion, by EN 13823:2010. Moreover, the enamels were subjected to thermogravimetric analysis with mass spectrometry to assess variations of mass during the temperature increase process. Lastly, a calorific value test was performed with the intent of comparing the values with those from the EN 13823:2010 test. It was noted that the paints evaluated, no matter their chemical composition, do not bolster the development of flames as they reduced smoke release by up to $6.7 \%$ and heat release by up to $60.4 \%$, not hindering user safety in room under fire situation. Even more, the paints turned out to be protectors of the substrate
\end{abstract}

Keywords: paints, finishing material, fire, building performance.

\section{INTRODUCTION}

Studying reaction to fire of covering and finish materials of buildings is essential to provide user safety. This fact is supported by the number of tragedies that have taken place, such as the ones that struck Grenfell Tower in 2017, in England, and left at least 80 dead [1]; the Kiss Nightclub in 2013, in Brazil, rendering 242 deaths [2]; and The Station nightclub in 2003, in the United States of America (USA), which led to the death of 100 people [3]. In these cases, the reaction to fire of covering and finish materials was a critical factor for the fast development of the fire, leading to numerous casualties and stressing the importance of this topic and the study of this area of knowledge within fire safety engineering.

Among the construction materials for which there is no detailed analysis with regards to reaction to fire lie the paints applied as covering and finish of sealing systems. The real estate market comprises $79 \%$ of the industry of paints manufactured in Brazil [4]. In the USA, paint industry grows $3.8 \%$ per year and has the civil construction as main demander [5]. According to da Silva [6], paints are made up of four basic components, which are binders (made of resins), solvents or thinners, pigments, and additives. They can be obtained from resins that are thermoplastic or thermofixed. The first are the water-based paints, and water is the main volatile agent of their composition, whereas acrylic resin is the most commonly used in civil construction $[4,6,7]$. The latter are oil-based paints, as they use oil as volatile agent of their composition, whereas alkyd resin is the most commonly used in industry of the oil-based paints.

Some paints can be flammable due to the addition of solvents and reducers to their composition [8], or by the presence of polymeric resin. However, few evidential studies that regard these materials and their use in real construction situations are known, which hints that further research is necessary to determine the influence of these on fire safety of buildings [9]. For finished buildings, the act of repainting the same element in sequent layers is common, leading to the formation a thick coat that can contribute towards the propagation of fire should the paint be based on flammable oil. 
The performance regulations of buildings designate minimum fire safety requirements, presented by NBR 15575 [10] in Brazil, by ICC Performance Code for Buildings and Facilities [11] in the USA, and by ISO 19208 [12] and ISO 15928-4 [13] as international directive for national regulations. One of the requirements is to prevent generalized inflammation, which requires an evaluation of the reaction to fire of finish and covering materials such as paints. Data about building paints under fire situation was not found. Therefore, this study aimed to evaluate reaction to fire of enamel paints used as wall finish materials of buildings. Two painting systems were defined, one water-based (acrylic resin) and one oil-based (alkyd resin), both applied over a substrate treated with solvent based undercoat, simulating the real conditions of application. For comparative purposes, a sample with no application of paint was subjected to the same tests

\section{MATERIALS AND METHODS}

The enamels were evaluated regarding their ignitability per ISO 11925-2:2010 [14] and a process of isolated combustion by EN 13823:2010 [15], as recommended the classification requirements imposed by regulations. The incombustibility test of ISO 1182:2010 [16] was not performed as it was impossible to adequate the material to the parameters set by the test standard, so the paints were assumed to be combustible. Moreover, the paints were subjected to thermogravimetric analysis with mass spectrometry to assess variations of mass during the temperature increase process. Lastly, a calorific value test was performed with the intent of comparing the values with those from the EN 13823:2010 [15] tests. Based on the results of calorific value determination for the enamel paints, performed by the bomb calorimeter as per DIN 51900:2005 [17] and ISO 1928:2009 [18], a comparative analysis was carried out with the values for total heat release of the sample during the first 600 seconds of exposure to flame (THR600s), from the EN 13823 [15] test, assessing possible similarities and differences between such values.

\subsection{Paints and substrate}

For this study, two types of paint were chosen to be analyzed (a) glossy white enamel paint based on hydrocarbon oil and (b) satin acrylic enamel paint based on water. These were applied over a frosted white undercoat to level the substrate and agglutinate loose particles present on the surface. The paints and their characteristics provided by the manufacturer are shown in Table 1.

Table 1: Characteristics provided by the manufacturer for the materials tested

\begin{tabular}{c|c|c|c|c|c|c}
\hline GENERIC NAME & MAIN RESIN & APPEARANCE & $\begin{array}{c}\text { PVC } \\
(\%)\end{array}$ & $\begin{array}{c}\text { SOLID RE- } \\
\text { SIN (\%) }\end{array}$ & $\begin{array}{c}\text { TOTAL } \\
\text { SOLIDS } \\
(\%)\end{array}$ & $\begin{array}{c}\text { MAIN VOLA- } \\
\text { TILE }\end{array}$ \\
\hline Oil-based enamel & $\begin{array}{c}\text { Long alkyd resin based on } \\
\text { soybean oil }\end{array}$ & Glossy & $15-16$ & $33-35$ & $58-60$ & Oil \\
\hline $\begin{array}{c}\text { Water-based ena- } \\
\text { mel }\end{array}$ & $\begin{array}{c}\text { Aqueous styrene acrylic } \\
\text { resin }\end{array}$ & Satin & $44-45$ & 24.5 & 50 & Water \\
\hline $\begin{array}{c}\text { Oil-based white } \\
\text { undercoat }\end{array}$ & $\begin{array}{c}\text { Long alkyd resin based on } \\
\text { soybean oil }\end{array}$ & Frosted & $54-55$ & $13-14$ & $57-58$ & Oil \\
\hline
\end{tabular}

The paints were applied over cement boards, in accordance with NBR 13245 [19]. These applications were performed on days at which the temperature was within the interval of $10^{\circ} \mathrm{C}$ and $40^{\circ} \mathrm{C}$ and humidity below 90\%, as NBR 13245 [19] specifies. The following tests were executed: ignitability, Single Burning Item (SBI), thermogravimetric analysis (TGA) and calorific value.

\subsection{Ignitability}

The test consists of applying a flame tip on an edge or on the surface of the sample, whichever is the worst exposure situation. Therefore, 10 specimens were prepared to represent the samples with sizes standardized by ISO 11925-2 [14], of 9x25cm, as Figure 1a shows. The variables evaluated during the tests were ignition of the sample, vertical flame spread and release of flammable particles. The test apparatus is depicted in Figure 1b. 


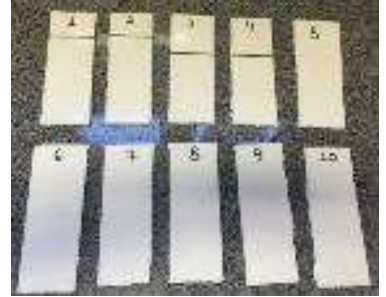

(a)

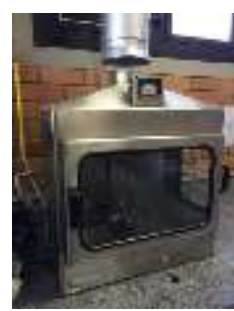

(b)

Figure 1: Ignitability test (a) samples, (b) apparatus

\subsection{Single Burning Item (SBI)}

The sample of the isolated combustion test, or Single Burning Item (SBI), defined by EN 13823 [15], is assembled on top of a mobile cart. The samples are positioned vertically over it and have an " $L$ " shape, measuring $1.00 \mathrm{~m} \times 1.50 \mathrm{~m}$ (long wing) and $0.495 \times 1.50 \mathrm{~m}$ (short wing). As the aim was to form wall corners, the cement boards were overlaid and fixed with metal clips, whereas no screws were needed, as shown in Figure 2a. To prevent these clips from interfering with the test results, due to the passing of air or layers of paint that were thicker than usual, silicone sealant category SIL 300 - Firestop sealant was used. The paints were applied 7 days after the application of the silicone, cure time specified by the manufacturer, assuring that the materials would not have chemical reactions between themselves, as depicted in Figure $2 b$

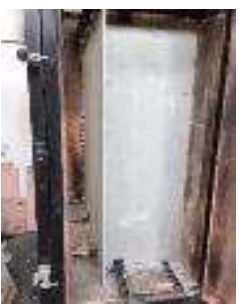

(a)

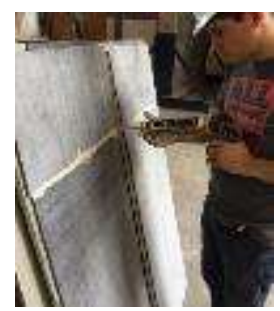

(b)

Figure 2: SBI test: (a) wall corners, (b) sealant being applied.

The SBI test was performed on 3 samples of each system. Initially, only the cement boards were subjected to the test, without the application of any kind of panting system, which served as reference to signalize changes that took place after the application of paint. Then, the samples covered with water-based and oil-based enamel paints were subjected to the test, rendering 9 tested samples in total. Figure $3 \mathrm{a}$ depict the exterior of the test apparatus, while Figure $3 \mathrm{~b}$ shows a representative sample of the system tested.

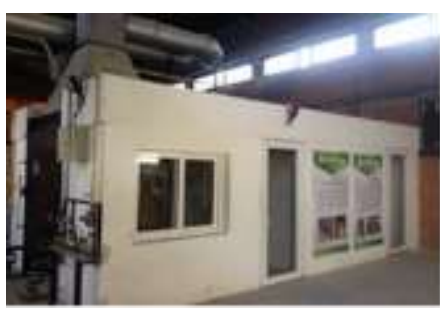

(a)

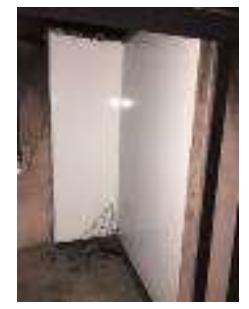

(b)

Figure 3: SBI test: (a) exterior of the SBI test apparatus and (b) representative sample of the system tested.

The test room had an exhaust duct equipped with sensors to measure temperature, fraction of $\mathrm{O} 2$ and $\mathrm{CO} 2$ moles, light attenuation and flow of differential pressure induced. These data were used for determining the fire growth rate index (FIGRA), total heat release of the sample during the first 600 seconds of exposure to flame (THR600s), smoke growth rate (SMOGRA), total smoke production of the sample during the first 600 seconds of exposure to flame (TSP600s), besides lateral flame spread (LFS) and flaming particles dropped on the sample, both of which were analyzed visually. 


\subsection{Thermogravimetric analysis (TGA)}

For this test, $20 \mathrm{mg}$ were extracted from each paint film. Thermogravimetric analysis is a thermal analysis which relies on monitoring losses of mass of a substance due to variations of temperature or exposure time of the sample in a place with controlled temperature and atmosphere.

First, $10 \mathrm{mg}$ of previously prepared ink film were put in a platinum crucible. The apparatus was closed with the sample inside and the temperature increased $10^{\circ} \mathrm{C} / \mathrm{min}$, projecting a maximum temperature of $850^{\circ} \mathrm{C}$ (temperature above generalized combustion). Residues were detected up to $790^{\circ} \mathrm{C}$, as the standard stated, in an oxidant test atmosphere (synthetic air) with $22 \%$ oxygen and $78 \%$ nitrogen, simulating the typical atmosphere. Then, the possible reactions during the paint pyrolysis process were investigated. This process was repeated twice, being once for each type of paint.

\subsection{Calorific Value}

The paint film was analyzed on this test. A layer of paint was applied over an inert substrate that would not loose particles, hence preventing interference with the results. Ceramic tiles were used for that purpose and $20 \mathrm{~g}$ were extracted from each paint film for the analysis of calorific value.

The bomb calorimeter test meets the requirements of DIN 51900 [17] and ISO 1928 [18] and is used to determine the calorific value generated during the combustion of the product that is being tested, in $\mathrm{MJ} / \mathrm{kg}$. The samples were tested for 8 minutes, with $0.5 \mathrm{~g}$ of paint surrounded by water in the combustion chamber. Next, a cotton wick was prepared, and the sample was set aflame with the electrical current from the terminals. The metal holder was then put in the bomb calorimeter, hermetically sealed and pressurized with 30 bars of pure oxygen.

After being pressurized, the vessel was installed within the combustion chamber, which is thermally isolated (adiabatic), surrounded by water. The amount of calorific value generated was determined in $\mathrm{MJ} / \mathrm{kg}$ from the water temperature variation during the combustion of the samples. In order to increase precision, a calorimeter with stirrer was used to homogenize the temperature values of the system, and a high precision thermometer was used to measure the temperature variation in the chamber during combustion.

\section{RESULTS AND DISCUSSION}

\subsection{Ignitability test}

The paint samples did not ignite, release flammable particles or spread flames. During the tests, blisters were formed on the paint films after their exposure to flames at 10 seconds for the oil-based paint and at 15 seconds for the water-based paint, fact that did not hinder their behavior. Figure 4 presents the systems after the ignitability test.

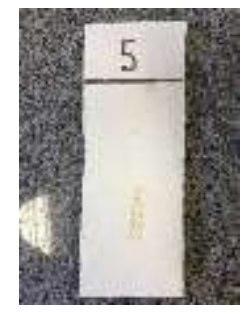

(a)

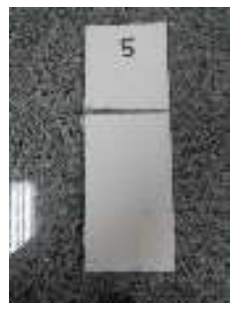

(b)

Figure 4: Samples after the ignitability test: (a) oil-based paint and (b) water-based paint.

Although the samples did not spread flames, the height of their carbonization was measured for a comparative analysis. Figure 5a presents the carbonization height of oil-based paint samples, exposed to flame on the surface. On the other hand, Figure $5 \mathrm{~b}$ shows the carbonization height of water-based paint samples, exposed to flame on the edge. 


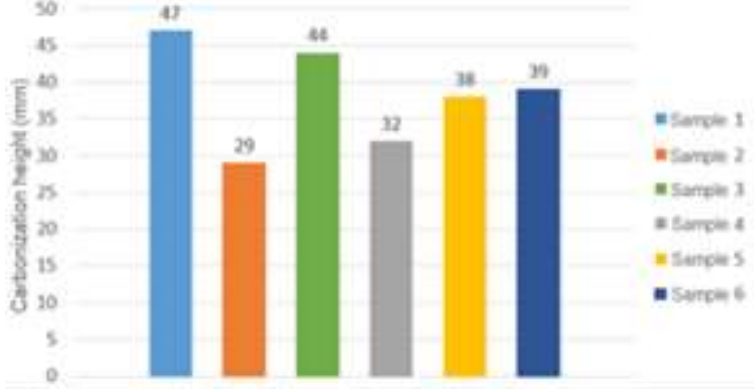

(a)

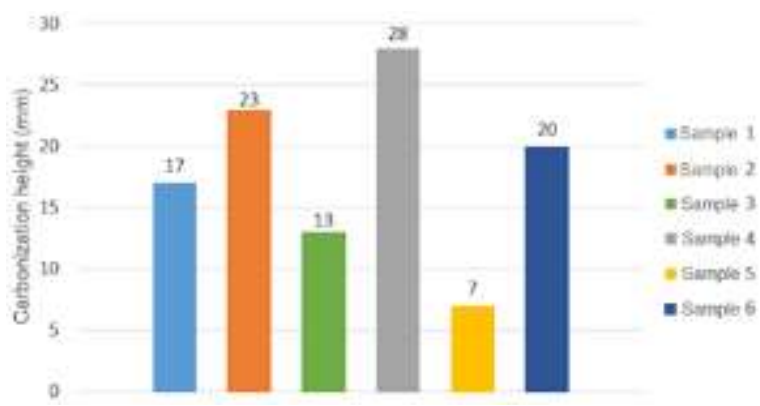

(b)

Figure 5: Carbonization height of the: (a) oil-based paint and (b) water-based paint.

The water-based paint displayed performance superior to that of the oil-based paint, as the first had maximum carbonization height of $28 \mathrm{~mm}$, while the latter reached maximum carbonization height of $47 \mathrm{~mm}$.

\subsection{SBI test}

Both types of paint subjected to this analysis performed better than the substrate without paint, reducing the indexes of heat and smoke production, providing protection to the substrate. This fact can be seen in Table 2, which shows average values for the performance of the paints compared with the substrate used for test parameters.

Table 2: Performance of the paint

\begin{tabular}{c|c|c|c}
\hline \multirow{2}{*}{ SBI RESULTS } & SUBSTRATE & \multicolumn{2}{|c}{ PAINTS } \\
\cline { 2 - 4 } & Cement board & Water-based & Oil-based \\
\hline FIGRA & $9.38 \mathrm{~W} / \mathrm{s}$ & $6.42 \mathrm{~W} / \mathrm{s}$ & $0.00 \mathrm{~W} / \mathrm{s}$ \\
\hline SMOGRA & $0.00 \mathrm{~m}^{2} / \mathrm{s}^{2}$ & $0.00 \mathrm{~m}^{2} / \mathrm{s}^{2}$ & $0.00 \mathrm{~m}^{2} / \mathrm{s}^{2}$ \\
\hline THR $_{600 \mathrm{~s}}$ & $1.39 \mathrm{MJ}$ & $0.97 \mathrm{MJ}$ & $0.55 \mathrm{MJ}$ \\
\hline TSP $_{600 \mathrm{~s}}$ & $24.24 \mathrm{~m}^{2}$ & $22.62 \mathrm{~m}^{2}$ & $24.29 \mathrm{~m}^{2}$ \\
\hline
\end{tabular}

It is possible to note from the comparison of both paints that the oil-based paint displays better performance. Considering heat production indexes, the oil-based paint performed better due to the total heat production (THP) drop, the reduction of the rate of heat generated per second (HRRav) and the absence of the fire growth rate index (FIGRA). However, the oil-based paint presented a decrease of performance with regards to total smoke production (TSP), whereas with little relevance seeing the absence of the samples' smoke generation rate (SMOGRA).

Figure $6 \mathrm{a}$ and Figure $6 \mathrm{~b}$ depict the performance of the paints compared to the substrate with regards to the total heat release during the first 600 seconds of exposure to flame, highlighted as 900 s because the first 300 s refers to the equipment calibration.

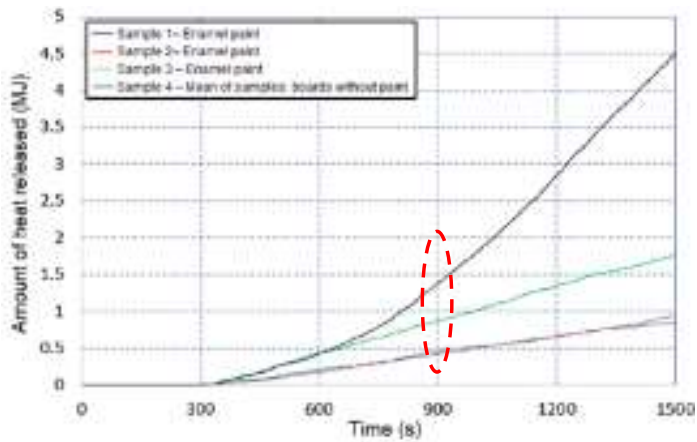

(a)

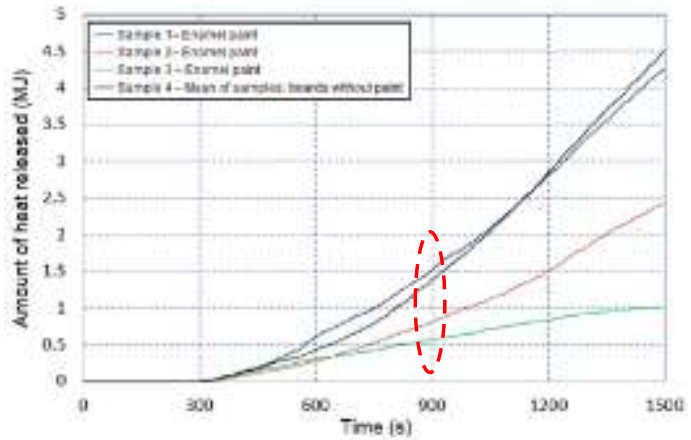

(b)

Figure 6: THR600s for: (a) oil-based paint and (b) water-based paint. 
The oil-based paint released $60.4 \%$ less heat than the substrate, while the water-based paint released $30.2 \%$ less heat, sustaining the superior performance of the oil-based paint. The performance of the samples turned out to be the opposite concerning for the total release of smoke during the first 600 seconds of exposure to flame, as presented in Figure $7 \mathrm{a}$ and Figure $7 \mathrm{~b}$.

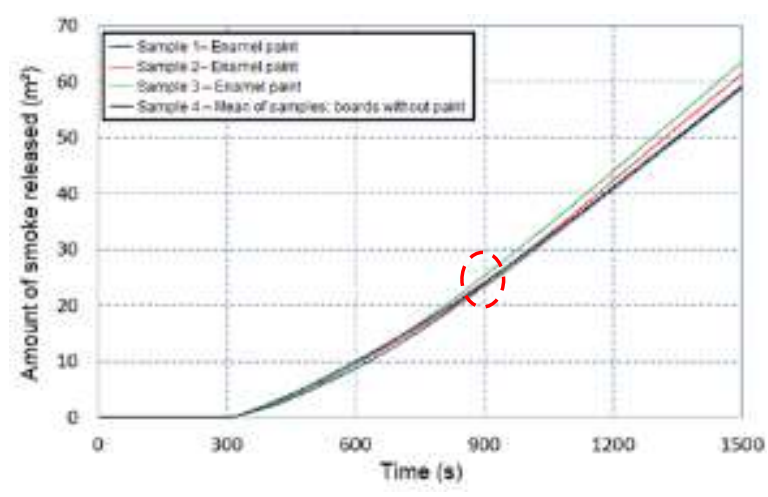

(a)

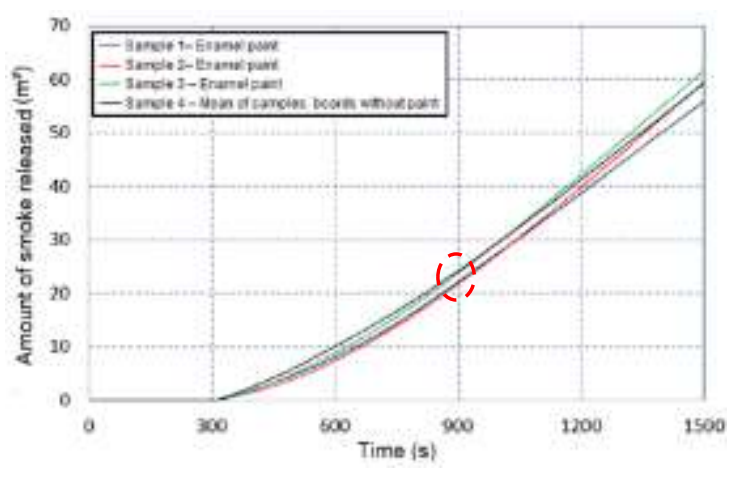

(b)

Figure 7: TSP600s for: (a) oil-based paint and (b) water-based paint.

The water-based paint released $6.7 \%$ less smoke than the substrate, whereas the oil-based paint released $0.2 \%$ more smoke.

Concerning lateral flame spread, the water-based paint demonstrated performance similar to that of the oil-based paint, although denoting smaller vertical carbonization height, conforming with the ignitability test results. In terms of maximum values, the first spread flames laterally on the long wing by $19 \mathrm{~cm}$ and vertically by $73 \mathrm{~cm}$, while the latter had the same lateral spread of $19 \mathrm{~cm}$, although with $77 \mathrm{~cm}$ of vertical spread. Table 3 summarizes the spreads of every painted sample tested, even though none of the two paints presented the lateral spread of flames (LSF) stated by the standard. Moreover, Figure 8 depicts three SBI samples after the test.

Table 3: Flame propagation of the SBI test

\begin{tabular}{c|c|c}
\hline SAMPLE NUMBER & $\begin{array}{c}\text { HEIGHT OF THE SPREAD } \\
\text { ON THE LONG WING (CM) }\end{array}$ & $\begin{array}{c}\text { WIDTH OF THE SPREAD } \\
\text { ON THE LONG WING (CM) }\end{array}$ \\
\hline Sample 1 - Oil-based & 75 & 19 \\
\hline Sample 2 - Oil-based & 77 & 19 \\
\hline Sample 3 - Oil-based & 73 & 19 \\
\hline Sample 1 - Water-based & 73 & 18 \\
\hline Sample 2 - Water-based & 64 & 19 \\
\hline Sample 2 - Water-based & 64 & 19 \\
\hline
\end{tabular}

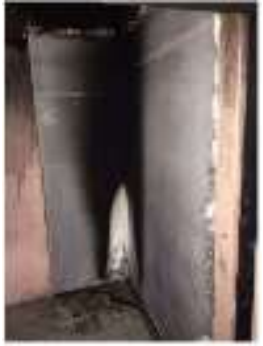

(a)

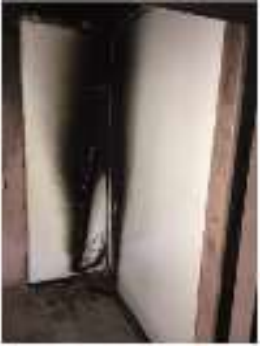

(b)

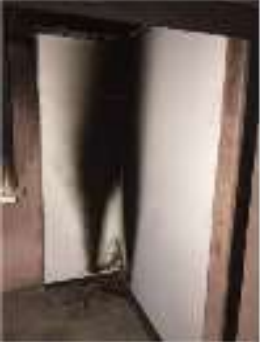

(c)

Figure 8: SBI samples after the test: (a) without paint, (b) oil-based paint, and (c) water-based paint.

The occurrence of blister on both paint films was observed during the SBI test, whose peeling took 
place only at the end of the test and may be related to the protection provided by the substrate during the exposure to flames. The blisters appeared at the 130 seconds of exposure to flames on the oil-based paint and at the 190 seconds on the water-based paint, a behavior that correlates to the one observed during the ignitability test, and that may be related to the amounts and characteristics of the of the volatile components of each paint.

\subsection{Thermogravimetric analysis}

After performing the tests, it was possible to determine the loss of mass and the probable moment at which the loosening of chemical elements (release of gasses) occurred by analyzing the combustion process during the pyrolysis of both water-based and solvent-based paints.

Figure 9 depicts the thermogravimetric analysis results for the oil-based paint, signifying mass loss peaks at $48.62^{\circ} \mathrm{C}$ (volatiles); $337.99^{\circ} \mathrm{C}, 439.44^{\circ} \mathrm{C}$ and $497.20^{\circ} \mathrm{C}$ (organics); and $656.17^{\circ} \mathrm{C}$ and $747.08^{\circ} \mathrm{C}$ (inorganics). These peaks show the temperatures at which the reactions took place in the paint, with loss of mass (release of gasses).

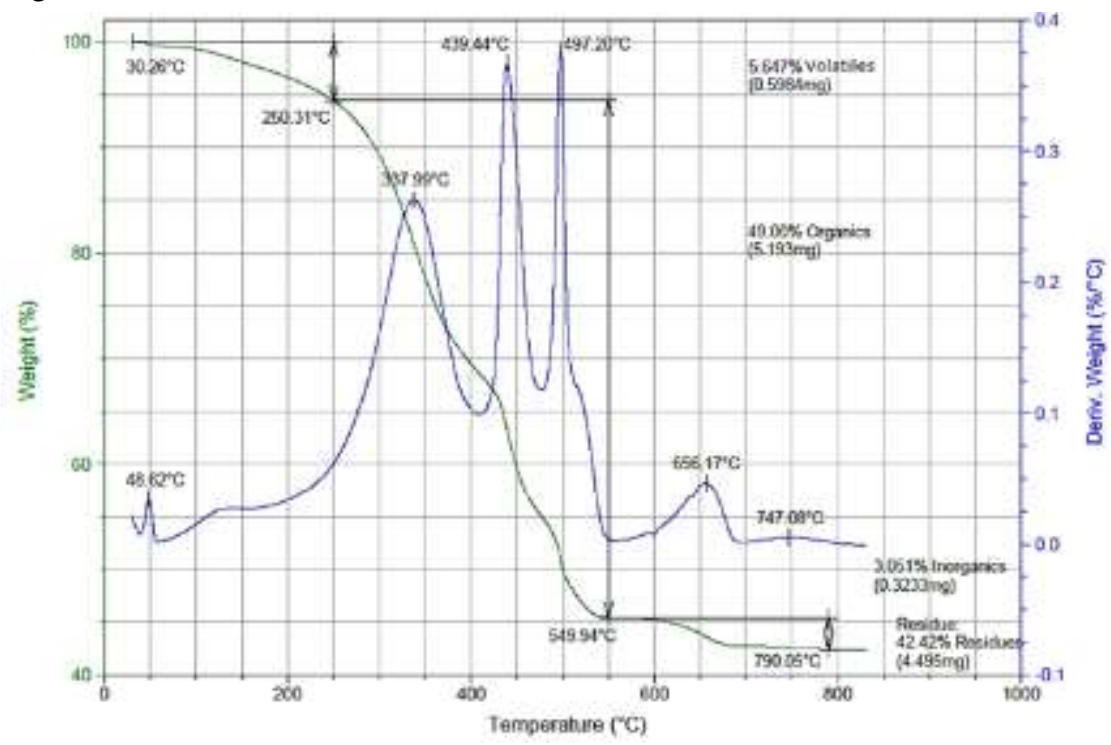

Figure 9: Thermogravimetric analysis results for the oil-based enamel paint.

The oil-based paint sample had initial mass of $10.596 \mathrm{mg}$. The increase of temperature showed that up to $250.31^{\circ} \mathrm{C}$ all volatiles (possibly additives and solvents) had been released, representing $5.647 \%$ of the sample's mass loss, or $0.598 \mathrm{mg}$. A sudden loss of mass was noted between $250.31{ }^{\circ} \mathrm{C}$ and $549.94^{\circ} \mathrm{C}$, motivated by the reaction of organic composites (most likely part of the long alkyd resin based on soybean oil, out of which the composition was made), which caused $49 \%$ of mass loss, or $5.193 \mathrm{mg}$. Finally, $3.051 \%$ of the mass was lost between $549.94^{\circ} \mathrm{C}$ and $790^{\circ} \mathrm{C}$ (maximum verification required by the standard), motivated by the reaction of inorganic materials (probably loads and inorganic pigments), releasing $0.323 \mathrm{mg}$ of mass. Only $42.42 \%$ of the initial sample was remaining by the end of the experiment, this being the residue considered as inert (probably made up of minerals) and representing $4.495 \mathrm{mg}$.

On the other hand, Figure 10 depicts the thermogravimetric analysis results for the water-based paint, showing mass loss peaks at $47.52^{\circ} \mathrm{C}$ and $128.37^{\circ} \mathrm{C}$ (volatiles); $375.77^{\circ} \mathrm{C}$ and $425.31^{\circ} \mathrm{C}$ (organics); and $649.7^{\circ} \mathrm{C}$ and $680.76^{\circ} \mathrm{C}$ (inorganics). 


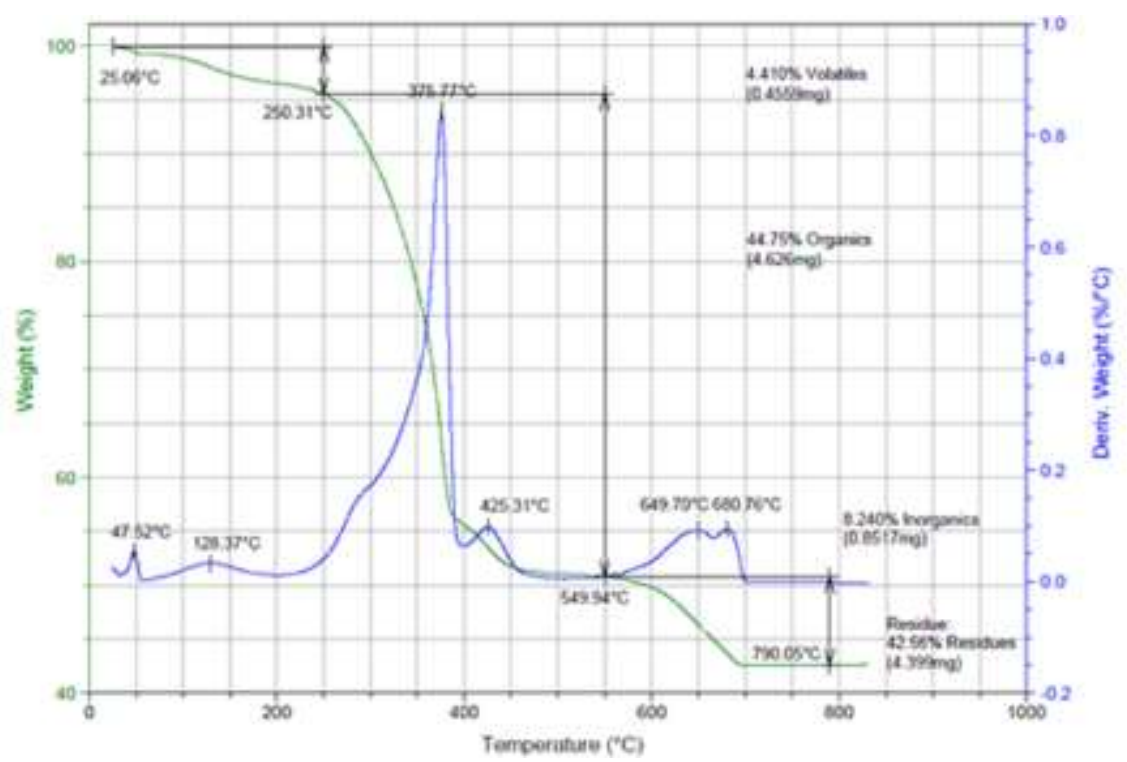

Figure 10: Thermogravimetric analysis results for the water-based enamel paint.

The water-based paint had an initial mass of $10.337 \mathrm{mg}$. The increase of temperature showed that up to $250.31^{\circ} \mathrm{C}$ all volatiles (possibly additives and diluents) had been released, representing $4.41 \%$ of the sample's mass loss, or $0.456 \mathrm{mg}$. Less volatiles were released by the water-based paint than the oil-based paint, most likely due to the absence of solvent in its composition. A sudden loss of mass was noted between $250.31^{\circ} \mathrm{C}$ and $549.94^{\circ} \mathrm{C}$, motivated by the reaction of organic composites (most likely the aqueous styrene acrylic resin), which caused $44.75 \%$ of mass loss, or $4.626 \mathrm{mg}$. The water-based paints also displayed smaller losses of mass from organic composites. Finally, $8.24 \%$ of the mass was lost between $549.94^{\circ} \mathrm{C}$ and $790^{\circ} \mathrm{C}$ (maximum verification required by the standard), motivated by the reaction of inorganic materials (probably loads and inorganic pigments), releasing $0.852 \mathrm{mg}$ of mass. The loss of mass from inorganic composites was much higher for the water-based paint, probably due to the loads that are added to the chemical composition of this type of paint. Barely $42.56 \%$ of the initial sample was remaining by the end of the experiment, this being the residue considered as non-volatile (probably made up of pigments that do not volatilize and minerals) and representing $4.339 \mathrm{mg}$.

\subsection{Calorific value}

The end of the tests led to the determination of the total amount of heat released and the variation of mass that occurred during the pyrolysis of the paints, as well as other transformations that the samples suffered.

The oil-based paint sample released $15.029 \mathrm{MJ} / \mathrm{kg}$ and lost $57.53 \%$ of their mass. This result is valid for all temperatures, as this test analyses the material's heat release value from the variation of temperature withstood by the water (at room temperature) during the process of complete combustion of the material. The amount of heat released by oil-based paints is smaller than the one of the main polymers studied by Walters, Hacket and Lyon [20], hinting that, for being considered a blend of several composites, paints do not pose substantial risk in comparison with polymer materials, for example.

Figure 11 depicts the condition of the sample after combustions, presenting spherical residues that used to be films originally. The loss of mass may have been caused by the volatility of some chemical composites (organic matter and solvents) that make up the composition of the paints. The formation of spherical residues presents similarities towards the reactions (blistering on the surface) that occurred during the tests of SBI and ignitability, right after exposure to flames. 


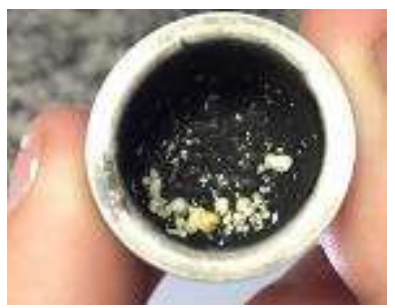

Figure 11: Residue for the oil-based enamel paint.

Table 4 presents the amount of heat a SBI sample would produce upon complete combustion, considering the values found during the calorific value test. The average total heat released during the first 600 seconds (THR600s) from SBI is smaller, 1.267MJ, while a SBI sample based on the calorific value test results would produce $16.095 \mathrm{MJ}$. This reveal yet another characteristic: the oil-based film is unable to spread flame throughout its surface during common fire situations, as it performs an incomplete combustion, hence not releasing the maximum amount of heat that would be possible. It should be noted that the SBI test was performed with the paint applied to a substrate which absorbs part of the paint film, while the heat value test is performed on the paint film exclusively, justifying this difference as well.

Table 4: Simulation of maximum heat produced by a SBI sample based on the calorific value results for oil-based paints.

\begin{tabular}{c|c|c}
\hline \multirow{4}{*}{ OIL-BASED PAINT } & Consumption per coat $\left(\mathrm{m}^{2} / \mathrm{l}\right)$ & 8.0 \\
\cline { 2 - 3 } & Application area $\left(\mathrm{m}^{2}\right)$ & 2.25 \\
\cline { 2 - 3 } & Amount of paint needed for 3 coats $(\mathrm{l})$ & 0.844 \\
\cline { 2 - 3 } & Density $(\mathrm{Kg} / \mathrm{l})$ & 0.774 \\
\cline { 2 - 3 } & Total weight $(\mathrm{Kg})$ & 0.653 \\
\hline \multirow{4}{*}{ WHITE UNDERCOAT } & Consumption per coat $\left(\mathrm{m}^{2} / \mathrm{l}\right)$ & 7.0 \\
\cline { 2 - 3 } & Application area $\left(\mathrm{m}^{2}\right)$ & 2.25 \\
\cline { 2 - 3 } & Amount of undercoat needed for 1 coat $(\mathrm{l})$ & 0.321 \\
\cline { 2 - 3 } & Density $(\mathrm{Kg} / \mathrm{l})$ & 1.3 \\
\hline PAINTING SYSTEM & Total weight $(\mathrm{Kg})$ & 0.418 \\
\hline AMOUNT OF HEAT & Total weight of the film $(\mathrm{Kg})$ & 1.071 \\
\cline { 2 - 3 } RELEASED & Heat released $(\mathrm{MJ} / \mathrm{Kg})$ & $\mathbf{1 6 . 0 9 5}$ \\
\hline
\end{tabular}

Like the oil-based paint results, the water-based paint results are valid for all temperatures, reaching heat release of $13.021 \mathrm{MJ} / \mathrm{Kg}$ and mass loss of $54.02 \%$. The value found is lower than those pertaining to the main polymers studied by Walters, Hacket and Lyon [20], as well as the amount of heat released by the oilbased paints, showing that a complete combustion of this type of paint would release less heat.

Figure 12 displays the residues of the water-based film after its combustion in the bomb calorimeter. These residues presented themselves as spherical fragments, just like those of the oil-based systems, losing mass during combustion, possibly due to the volatility of some chemical composites (organic matter and solvents) that are part of the composition. The formation of residues brings similarities with the reactions (blistering on the surface) that were observed during the tests of SBI and ignitability, whereas this phenomenon was less substantial for the water-based covers (smaller \% of mass loss and blistering taking longer to start). 


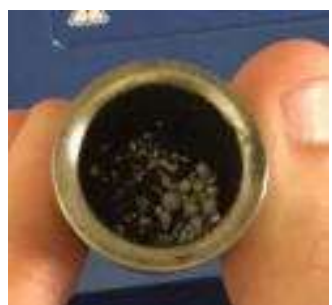

Figure 12: Residue for the water-based enamel paint.

Table 5 presents the amount of heat that would be released by a sample covered with water-based enamel paint upon complete combustion during the SBI test, considering the calorific value test results. The average total heat released during the first 600 seconds (THR600s) from SBI is smaller, 2.767MJ, while a sample based on the calorific value test results would produce $11.589 \mathrm{MJ}$. Like what happened to the oilbased paints, the water-based paints are unable to spread flame throughout its surface during common fire situations, as they perform an incomplete combustion, hence not releasing the maximum amount of heat that would be possible.

Table 5: Simulation of maximum heat produced by a SBI sample based on the calorific value results for oil-based paints.

\begin{tabular}{c|c|c}
\hline \multirow{4}{*}{ OIL-BASED PAINT } & Consumption per coat $\left(\mathrm{m}^{2} / \mathrm{l}\right)$ & 16.0 \\
\cline { 2 - 3 } & Application area $\left(\mathrm{m}^{2}\right)$ & 2.25 \\
\cline { 2 - 3 } & Amount of paint needed for 3 coats $(\mathrm{l})$ & 0.422 \\
\cline { 2 - 3 } & Density $(\mathrm{Kg} / \mathrm{l})$ & 1.12 \\
\cline { 2 - 3 } & Total weight $(\mathrm{Kg})$ & 0.472 \\
\cline { 2 - 3 } & Consumption per coat $\left(\mathrm{m}^{2} / \mathrm{l}\right)$ & 7.0 \\
\cline { 2 - 3 } WHITE UNDERCOAT & Application area $\left(\mathrm{m}^{2}\right)$ & 2.25 \\
\cline { 2 - 3 } & Amount of undercoat needed for 1 coat $(\mathrm{l})$ & 0.321 \\
\cline { 2 - 3 } & Density $(\mathrm{Kg} / \mathrm{l})$ & 1.3 \\
\hline \multirow{2}{*}{ PAINTING SYSTEM } & Total weight $(\mathrm{Kg})$ & 0.418 \\
\hline AMOUNT OF HEAT & Total weight of the film $(\mathrm{Kg})$ & 13.021 \\
\cline { 2 - 3 } RELEASED & Heat released $(\mathrm{MJ} / \mathrm{Kg})$ & $\mathbf{1 1 . 5 8 9}$ \\
\cline { 2 - 3 } & Total heat released by SBI sample $(\mathrm{MJ})$ & \\
\cline { 2 - 3 }
\end{tabular}

\section{CONCLUSIONS}

This article studied the performance to fire of oil-based and water-based enamel paints used in buildings, evaluating them through an experiment following requirements set by regulations and calling attention to possible risks that the application of these materials may pose to fire safety of buildings and the influence these materials exert on design making. In this context, it was noted that the paints have little influence when subjected to a fire situation. Moreover, the paints that were tested improved, in a general way, the performance of the substrate during fire development, as they did not contribute towards the development of flames or the occurrence of flashover, given that the amount of heat released reduced and the difference of smoke released was insignificant. The paints also turned out to be incapable of performing complete combustion during common fire situation, supporting the hypothesis that paints do not pose risks in cases of tragedy and allowing the paint to be applied to any room to which flammable materials may be applied. 


\section{BIBLIOGRAPHY}

[1] BBC, http://www.bbc.com/news/uk-england-london-40272168. Accessed in 25 October 2017.

[2] G1, http://g1.globo.com/rs/rio-grande-do-sul/noticia/2013/01/tragedia-em-santa-maria-o-que-ja-se-sabee-perguntas-responder.html. Accessed in 25 October 2017.

[3] GROSSHANDLER, W., et al., "Report of the technical investigation of the station nightclub fire", In: NIST NCSTAR 2, v. 1, National Institute of Standards and Technology, Gaithersburg, 2005.

[4] DONADIO, P. A. (2011), Manual Básico Sobre Tintas. Águia Química, Ponta Grossa, Brazil.

[5] THE FREEDONIA GROUP, https://www.freedoniagroup.com/industry-study/paint-coatings-3317.htm. Accessed in 25 October 2017.

[6] SILVA, J. D. C., Estudo das Tintas Autolimpantes e Purificadoras, MSc. Thesis., Department of Engineering, Minho University, Braga, Portugal, 2013.

[7] POLITO, G., Principais Sistemas de Pinturas e suas Patologias, Engineering Department of Federal University of Minas Gerais, Belo Horizonte, Brazil, 2006.

[8] HERRMANN, R., http://www.rennercoatings.com/hotsite/site/medidas_seguranca.html. Accessed in 25 June, 2017.

[9] SANTOS, C. P. (2014), Comportamento dos materiais na legislação de SCIE e possíveis evoluções na perspectiva do LNEC. Laboratório Nacional de Engenharia Civil, Lisbon, Portugal.

[10] NBR-15575-4: Edificações habitacionais - Desempenho Parte 4: Sistemas de vedações verticais internas e externa, Rio de Janeiro, ABNT - Associação Brasileira de Normas Técnicas.

[11] 2018 ICC Performance Code for Buildings and Facilities, Country Club Hills, ICC - International Code Council.

[12] ISO 19208: framework for specifying performance in buildings. Brussels, ISO - International Organization for Standardization.

[13] ISO 15928-4: Houses - Description of performance - Part 4: Fire safety, Brussels, ISO - International Organization for Standardization.

[14] ISO 11925-2: Reaction to fire tests - Ignitability of building products subjected to direct impingement of flame - Part 2: single-flame source test, Brussels, ISO - International Organization for Standardization.

[15] BS EN 13823: Reaction to fire tests for building products - Building products excluding floorings exposed to the thermal attack by a single burning item. Brussels, CEN - European Committee for Standardization.

[16] ISO 1182: Buildings materials - non - combustibility test. Brussels, ISO - International Organization for Standardization.

[17] DIN 51900: Determining the gross calorific value of solid and liquid fuels using the bomb calorimeter, and calculation of net calorific value, Germany, DIN - German Institute for Standardization.

[18] ISO 1928: Solid mineral fuels -- Determination of gross calorific value by the bomb calorimetric method and calculation of net calorific value, Brussels, ISO - International Organization for Standardization.

[19] NBR-13245: Tintas para construção civil - Execução de pinturas em edificações não industrias - Preparação de superfície. Rio de Janeiro, ABNT - Associação Brasileira de Normas Técnicas.

[20] WALTERS, R. N., HACKETT, S. M., LYON, R. E., "Heats of combustion of high temperature polymers", Fire and Materials, v. 24, n. 5, pp. 245-252, Sep. 2000.

\section{ORCID}

Guilherme Hennemann

Henrique Eugenio

Fabrício Bolina

Eduardo Estevam Rodrigues

Bernardo Fonseca Tutikian https://orcid.org/0000-0003-1059-4327

https://orcid.org/0000-0002-1706-6220

https://orcid.org/0000-0002-0495-099X

https://orcid.org/0000-0002-1469-0693

https://orcid.org/0000-0003-1319-0547 